Diterima : 8-5-2020

Revisi : 21-6-2020

Dipublikasi : 25-6-2020

\title{
HARMONISASI DALAM KOMUNIKASI GURU DAN SISWA DI ERA MILENIAL MELALUI BAHASA INDONESIA DAN BAHASA TUBUH YANG BERETIKA
}

\author{
Hetty Purnamasari \& Imron Amrullah \\ Universitas Dr. Soetomo \\ Jl. Semolowaru no 84 Menur Pumpungan, Kota Surabaya, Indonesia \\ Poe-el : hettypurnamasari4827@gmail.com
}

\begin{abstract}
Efforts have been made to improve the quality of education and develop the character and culture of the nation, especially by educators. The phenomenon of Indonesian people's lives which shows the weakening of the character and culture of the nation which has been believed to have been a characteristic of the Indonesian Nation. Related to this, the problem of a teacher in guiding and fostering their students is very complex. This happens because of many phenomena, one of which is the rise of global culture and the lifestyle of Pop Culture, life tends to be hedonist. People who do not follow this lifestyle will feel inferior. This phenomenon is considered as the impact of the current of globalization which is no longer possible to stem.
\end{abstract}

Keywords : global culture, pop culture

\begin{abstract}
Abstrak
Usaha untuk meningkatkan kualitas pendidikan dan mengembangkan karakter dan budaya bangsa telah banyak dilakukan, terutama oleh para pendidik. Fenomena kehidupan masyarakat Indonesia yang menunjukkan semakin lemahnya karakter dan budaya bangsa yang selama ini diyakini telah menjadi ciri khas Bangsa Indonesia. Terkait dengan hal tersebut, permasalahan seorang guru dalam membimbing dan membina anak didiknya sangatlah kompleks. Hal ini terjadi karena banyak fenomena, salah satunya maraknya budaya global dan gaya hidup budaya pop, kehidupan cenderung hedonis. Masyarakat yang tidak mengikut gaya hidup demikian, akan merasa sebagai inferior. Fenomena ini dianggap sebagai dampak dari arus globalisasi yang sudah tidak mungkin dibendung lagi.
\end{abstract}

Kata-kata Kunci : budaya global, budaya pop 


\section{PENDAHULUAN}

Generasi Milenial dikenal sebagai generasi $Y$, adalah kelompok demografi setelah generasi $X$. Tidak ada batas yang pasti untuk awal dan akhir dari kelompok ini. Generasi Millenial adalah generasi muda yang berumur 1737 th pada tahun ini.

Ciri-ciri generasi ini adalah lebih percaya pada pengalaman dari pada iklan, lebih memilih ponsel dibanding TV, wajib mempunyai Medsos, mulai banyak melakukan transaksi secara cashless, kurang suka membaca secara konvensional, lebih paham teknologi dibanding orang tuanya, cenderung tidak loyal, namun bekerja efektif (Cornelia, 2017). Dengan demikian, pada generasi ini akan membentuk sebuah komunitas yang tidak terlalu dekat dan loyal, karena dunia dan kehidupannya lebih dekat dengan sebuah benda yang justru dianggap Dewa. Tetapi memutus kedekatan tersebut dengan cara ekstrem akan menimbulkan permasalahan baru. Namun demikian, tidak berarti bisa mengikuti semua apa yang dikehendaki oleh siswa yang keblinger dengan gaya hidup era millennial. Tetapi orang tua dan guru bisa mengarahkan dan memanfaatkan sarana canggih tersebut untuk sebuah upaya kehidupan yang lebih baik. Tugastugas bisa memanfaatkan aplikasi atau HP untuk memancing kreativitas siswa berbuat lebih.

Namun demikian, banyak generasi millennial yang mampu berprestasi dan mampu memanfaatkan sarana untuk sebuah kegiatan yang baik dan bahkan menghasilkan, seperti adanya penjualan On Line, adanya Gojek, Gocar, Gofood, Gosend dan Go yang lain. Generasi ini sudah demikian bersahabat dengan $\mathrm{HP}$, medsos dan beberapa aplikasi, termasuk ruang guru yang dianggap jauh lebih murah, lebih efektif dan ada embel-embel "lebih gaul". Belajar bahasa asing dan tuntunan ibadah semua bisa dipejari melalaui aplikasi. Gaya hidup gaul dianggap sebagai sebuah prestise yang layak dijaga agar bisa terterima di lingkungan yang diinginkannya.

Menghadapi generasi Millenial harus lebih masuk pada dunia mereka, karena mereka mempunyai dunia yang unik jika dibandingkan dengan generasi sebelumnya, karena dampak dari kemajuan teknologi. Ada kesan generasi sebelumnya lebih sopan, dan etis disbanding generasi

\section{A. Potret Bahasa Indonesia di Era Millenial \\ Bahasa Indonesia merupakan bahasa nasional yang memiliki jiwa mempersatukan budaya bangsa Indonesia. Pembelajaran Bahasqa Indonesia memiliki peranan yang sangat penting bukan hanya untuk membina ketrampilan komunikasi}


melainkan juga untuk penguasaan ilmu, komunikasi dengan berbagai generasi. Dalam pembelajaran bahasa Indonesia dan mata pelajaran yang lain, pendidikan karakter dapat diintegrasikan dalam proses pembelajaran itu sendiri. Selain itu, pengintegrasian pendidikan karakter dapat melalui komunikasi yang harmonis antara siswa dengan guru dan tendik, dan siswa dengan orang tua dan lingkungannya. Dalam konteks sekolah, bahasa yang digunakan komunikasi, bukan hanya untuk kepentingan pembelajaran tetapi juga untuk mempelajari dunia siswa, pergaulan, prestise dan apresiasi tertentu.

Benarkah Bahasa Indonesia memudar di Generasi Millenial, padahal Bahasa Indonesia adalah salah satu komponen dalam membangun karakter bangsa? Seiring berjalannya waktu, keinginan belajar bahasa asing justru membuat bahasa Indonesia terpinggirkan. Banyak anak usia sekolah, terutama kaum Millenial yang tinggal di kota besar tampak gagap berbahasa Indonesia, di antara mereka bahkan banyak yang lebih fasih menggunakan bahasa asing. Interferensi bahasa tidak bisa dihindarkan dan semakin menghilangkan wujud asli bahasa Indonesia. Bahasa Indonesia memang terlalu berjenjang seperti layaknya dalam bahasa Jawa, namun demikian beberapa istilah tidak bisa digunakan ketika kita berhadapan dengan lawan bicara yang berbeda.
Bahasa Indonesia bukan sekedar alat komunikasi atau tutur kata. Bahasa ikut menggambarkan budaya dan jati diri bangsa, budaya daerah dan pribadi tertentu. Terutama dalam ekspresi karakter pribadi yang dipengaruhi oleh kompleksnya permasalahan. Dalam Bahasa Indonesia terdapat perbedaan ketika berbicara dengan teman sebaya, orang yang lebih tua, guru dan orang tua. Sering untuk lebih sopan atau menghotmati orang yang kita ajak bicara, harus dilakukan interferensi dengan bahasa daerah. Misalnya: "Nyuwun ngapunten, apa benar ini rumah Ibu $X^{\prime \prime}$ dan sebagainya.

Di sisi lain pada era millennial banyak siswa menggunakan bahasa gaul. Biasanya istilah yang digunakan bukan kata baku yang ada dalam bahasa Indonesia. Para warganet lebih sering menyebutnya sebagai bahasa gaul anak zaman 'now'. contohnya: Kepo (Knowing Every Particular Object) yang artinya ingin tahu atau ingin tahu banget; Keleus merupakan plesetan dari kata kali, misalnya biasa aja keleus (biasa aja kali); bro, merupakan kata panggilan akrab teman; Woles, artinya santai berasal dari kata slow yang pengucapannya dibalik; Baper, bawa perasaan, maksudnya menunjukkan orang yang mudah tersinggung; san, artinya santai; komuk, muka atau wajah; Rempomg, ribet atau bertele-tele dan seterusnya.

Benarkah bahasa gaul mampu mengakrabkan antara 
penutur dan petutur? Benarkah bahasa gaul dapat mempermudah komunikasi di era millennial? Dalam bahasa gaul hampir tidak ada jenjang pemakaian. Di sisi lain kita tidak bisa menciptakan jarak dengan munculnya bahasa gaul ini. Apabila memenaragadingkan diri dari bahasa gaul, maka kita justru akan membentangkan jarak dengan generasi millennial, para guru juga akan sulit masuk ke dunia generasi ini. Bagaimana mungkin bisa mendampingi dan membimbing generasi ini, kalau kita tidak paham dunia mereka. Tidak biasa mengetahui apa yang diinginkan dan apa yang tidak mereka sukai untuk berkomunikasi di semua lini dalam pergaulan. Fenomena munculnya bahasa gaul sebenarnya sudah lama beredar, bahkan sering kali menjadi sebuah solusi untuk menambah keakraban dalam komunikasi lisan maupun tulis. Dengan meluasnya bahasa gaul melalui medsos dan televise, masyarakat lebih tahu dan mengenal. Bagaimana dengan uapaya pembatasan penggunaan bahasa gaul di lingkungan sekolah sebagai perintis dan pengawal dalam penegakan kembali pada bahasa Indonesia yang berkarakter?

Eksistensi bahasa Indonesia perlu dibina dan dimasyarakatkan oleh setiap warga Negara Indonesia, agar bahasa Indonesia tidak terbawa arus atau pengaruh popularitas bahasa gaul yang semakin popular. Ini semua menyangkut kedisiplinan berbahasa nasional yang menyangkut aturan dalam berbahasa Indonesia yang baik dan benar. Dengan disipilin berbahasa Indonesia akan membantu bangsa Indonesia untuk mempertahankan diri dari pengaruh negative. Di antara masyarakat masih banyak yang merasa inferior ketika menggunakan bahasa Indonesia di lingkungan tertentu.

Sorang penutur sering dianggap tidak gaul ketika tidak bisa memaknai sebuah istilah yang popular dalam bahasa gaul. Sikap sebuah komunitas yang demikian akan menyeret pengguna bahasa Indonesia ke dalam sebuah lingkaran "dwi bahasawan". Padahal penggunaan bahasa daerah juga masih banyak digunakan sebagai bahasa Ibu. Terlalu banyak menggunakan bahasa daerah dan bahasa gaul memang bisa mendekatkan diri secara psikososial karena merasa satu komunitas, namun demikian juga rawan adanya perbedaan pemahaman karena bagaimana pun ada sebuah perbedaan wilayah antara guru dan tenaga pendidikan dengan siswa.

\section{B. Bahasa Tubuh dan Penggunaannya}

Bahasa tubuh seeorang sangat mendukung makna bahasa lisannya, bahkan bahasa tubuh pada beberapa hal bisa menggantikan bahasa lisan. Ekpresi, postur tubuh, warna pakaian (dalam keadaan tertentu), wajah (mimic wajah), gestur (gerakan tangan) dan gerakan tubuh yang lain adalah 
bagian dari bahasa tubuh untuk berkomunikasi secara non verbal. Menurut para ahli, bahasa tubuh ditunjukkan secara alami, ketika seseorang ingin menyampaikan informasi, tapi tidak bisa diucapkan dengan kata-kata. Misalnya karena merasakan sesuatu setelah adanya komunikasi atau melihat atau mendengar sesuatu tiba-tiba seseorang bisa tertawa atau menangis. Itulah sebabnya membaca bahasa tubuh seseorang sangat penting untuk memahami situasi. Bahasa tubuh bersifat universal atau umum, artinya setiap orang di dunia menggunakannya tanpa dibatasi oleh bahasa. Untuk memaknai bahasa tubuh ada beberapa hal yang harus diperhatikan:

1. Ekspresi wajah penutur Bahagia, sedih, marah, bingung, takut, menghina, mengejek, kaget dll).

2. Mata, mata mampu mengungkapkan banyak hal, baik itu yang sedang dirasakan, atau dipikirkan seseorang yang bias dilihat dari gerakan matanya. Ketika seseorang melihat langsung ke mata anda saat melakukan percakapan, hal ini menunjukkan bahwa ia tertarik dan memperhatikan topik pembicaraan. Namun bila kontak mata dilakukan cukup lama dan tajam, bias ditengarai tanda adanya ancaman. Hal lain yang mungkin terjadi adalah kedipan mata, orang yang sering berkedip lebih cepat jika mereka merasa tertekan, tidal nyaman atau sedang berbohong

3. Gerakan bibir, Gerakan bibir lawan bicara bisa

diperhatikan terutama saat tersenyum, senyum tidak selalu pertanda rasa senang atau bahagia, banyak emosi yang bias ditutupi dengan senyuman.

4. Gestur, Gestur merupakan sinyal bahasa tubuh yang paling jelas dan mudah dimengerti, namun tidak semua Negara memaknai gesture dengan arti yang sama. Misalnya acungan

Jempol bias bermakna hebat, di Negara Iran bermakna terserah.

5. Posisi tangan dan kaki, posisi lengan dan kaki juga berguna untuk menyampaikan informasi secara tidak langsung.

6. Postur tubuh, Orang yang memiliki posisi duduk tegak menunjukkan bahwa ia orang yang focus dan memperhatikan hal yang sedang dilakukan, sebaliknya orang yang dalam posisi duduk dengan membungkuk ke depan atau ke sisi lain mengisyaratkan kebosanan atau ketidakpedulian.

Bahasa tubuh mempunyai makna symbol yang sering juga disalah tafsirkan dan 
menimbulkan masalah. Bahasa tubuh sangat visual dan mudah ditangkap oleh lawan bicara. Ketika seorang guru mengucapkan kalimat "begini anak-anak, tolong perhatikan penjelasan saya ..." dengan ekspresi ingin menjelaskan sesuatu, pasti dianggap sah-sah saja. Tetapi sebaliknya ketika kalimat tersebut diucapkan oleh seorang siswa pada seorang guru "Begini Bapak/Ibu, tolong perhatikan penjelasan saya, ..." tentu dianggap sudah tidak sopan. Kalimat tersebut akan lebih sopan apabilan diganti dengan "Maaf Bapak/Ibu, dapatkah saya memberi penjelasan tentang hal tersebut ..." (tidak terkesan memerintah). Kalimat ini akan didukung dengan bahasa tubuh yang menunjukkan adanya sebuah penghormatan. Tanpa kalimat, bahasa tubuh untuk menghormati, kasih sayang, merendahkan, menantang dan kecewa bisa ditangkap dan dimaknai oleh lawan tutur.

\section{Komunikasi yang beretika}

Pembelajaran yang harmonis merupakan kondisi pembelajaran yang mampu merangsang guru dan siswa bekerja secara aktif sesuai dengan tugas dan fungsinya. Dalam kehidupan masyarakat Indonesia telah terjadi berbagai perubahan, baik sebagai akibat tatanan baru kehidupan dunia dan perkembangan ilmu pengetahuan serta teknologi informasi maupun akibat peristiwa alam. Dalam kaitan dengan tatanan baru kehidupan dunia, globalisasi, arus barang dan jasa termasuk tenaga kerja asing yang masuk ke Indonesia sudah demikian tinggi. Tenaga kerja dan wisatawan masuk ke indonsia dengan membawa budaya mereka dalam kehidupan masyarakat Indonesia. Kondisi tersebut telah menempatkan budaya asing pada posisi strategis yang memungkinkan pengaruh budaya tersebut memasuki berbagai sendi kehidupan bangsa dan memengaruhi perkembangan perilaku masyarakat indonesia. Perubahan perilaku masyarakat ini mempengaruhi perilaku dalam komunikasi.

Komunikasi adalah proses yang di dalamnya menunjukkan arti pengetahuan dipindahkan dari seseorang kepada orang lain, biasanya dengan maksud untuk mencapai beberapa tujuan khusus ( Herbert, 1991). Fungsi Komunikasi:

1. Membangun Konsep diri

2. Eksistensi

3. Kelangsungan hidup

4. Memperoleh kebahagiaan

5. Terhindar dari tekanan dan ketegangan

Permasalahan siswa di sekolah demikian kompleks yang tidak dapat diselesaikan demikian saja dengan membebankan pada guru dan tenaga kependidikan di sekolah.

Untuk memecahkan permasalahan-permasalahan tersebut diperlukan peran guru kelas yang mampu memahami 
karakter siswa sebagai wadah untuk memberikan analisis dan solusi bagi permasalahan siswa. Memang tidak semua permasalahan mampu diselesaikan di sekolah, karena beberapa permasalahan siswa berlatar belakang dari lingkungan $n$ kondisi siswa di rumah. Oleh sebab itu semua personil di sekolah wajib dilibatkan dalam proses pembibimbingan. Di samping itu, keterlibatan orang tua siswa sangat diperlukan untuk mendapatkan informasi kondisi siswa di luar sekolah.

Dari sebab-sebab perubahan keadaan sosial dan ekonomi berpengaruh pada perilaku masyarakat. Fenomena "keterbukaan" yang menurut anggapan beberapa orang dipandang sebagai suatu aplikasi tindak demokratis, menyebabkan perilaku-perilaku yang merugikan orang lain (anak). Dampak dari reformasi adanya sikap keterbukaan di masyarakat, tidak terkecuali orang-orang tua dan anak-anak. Masyarakat semakin bisa membuka diri terhadap segala hal yang baru dan kritikan. Anak-anak semakin leluasa menanyakan segala hal yang mengusiknya untuk ingin tahu yang sering juga berbenturan dengan hal yang dianggap orang tua masuk ranah "etika", sehingga dianggap tidak layak untuk ditanyakan apalagi diberi jawaban. Tetapi tidak jarang orang tua yang tidak bisa menjawab berusaha menghindar dengan alasan pertanyaan tidak pantas, sibuk atau alasan lain yang sering hanya merupakan sebuah upaya untuk ngeles.

Etika yaitu system yang mengatur bagaimana seorang manusia itu bergaul. Sistem pergaulan tersebuat menjadi pedoman untuk saling menghormati (sopan santun). Maksud pedoman tersebut untuk menjaga kepentingan masingmasing yang terlibat, agar mereka tenang, terlindung dan bahagia. Oleh sebab itu Etika tidak lain adalah aturan perilaku, adat ke biasaan manusia dalam pergaulan antar sesamanya dan menegaskan mana yang baik dan mana yang buruk. Dalam bahasa Yunani Ethos, artinya norma, nilai, kaidah dan ukuran bagi tingkah laku manusia yang baik. Di dalam etika sosial, seseorang berbicara menyangkut kewajiban, sikap dan pola perilaku manusia.

Komunikasi yang baik antara guru, tenaga kependidikan dan siswa akan menciptakan suasana yang nyaman. Untuk mencapai hal tersebut harus ada pemahaman yang bias dimaknai semua jajaran, adanya bahasa yang sama adanya sebuah pemahaman tanda dalam pemahaman yang sama antara petutur dan penutur baik dalam bahasa lisan maupun dalam bahasa tulis terutama komunikasi melalui HP. Perbedaan pemahaman dalam memaknai sebuah teks akan bisa menimbulkan masalah, masalah yang sering terjadi akibat hal tersebut adalah adanya ketersinggungan. 
Masalah tersinggung, bisa berdampak kesedihan, kemarahan bahkan sampai pada perkelahian. Dengan pemahaman bahasa (lisan, tulisan dan bahasa tubuh) yang sama akan meminimalisasi adanya sebuah perbedaan persepsi. Dalam bahasa Indonesia ada tataran yang harus diperhatikan ketika seorang berbicara dengan siapa. Dalam bahasa tubuh pun juga ada sebuah tataran yang bisa dilakukan dan tidak ketika kita sedang berbicara dengan seseorang atau dalam forum tertentu.

Beberapa orang sering tidak menyadari adanya sebuah perilaku/ tindakan main-main yang berdampak buruk pada seseorang/ anak. Misalnya beberapa orang memanggil nama anak dengan sebutan-sebutan negatif, dengan alasan nama kesayangan/agar lebih akrab dll. Misalnya penyebutan "Bongkok", "Lemot", "Brontok" dll yang menggambarkan kelemahan fisik seseorang. Perilaku sosial ini dapat menyebabkan perasaan minder atau merasa direndahkan tanpa bisa melakukan sebuah protes/ perlawanan. Keadaan ini juga dapat menyebabkan seorang anak merasa tidah dihargai/ direndahkan. Dengan demikian dampak secara sosial bahwa dia tidak merasa sepadan dengan teman-teman lain bisa berakibat anak tersebut akan menarik diri dari lingkungan sosialnya karena dia tidak merasa nyaman. Selain dampak sosial dampak psikologis pada anak tersebut juga harus diwaspadai. Dengan melakukan pengamatan pada perubahan perilaku anak sehari-hari. Apabila anak sampai merasa sakit hati dan memendam rasa dendam akan meracuni psikisnya.

Sebaliknya seorang siswa juga harus menghindari label buruk dan penyebutan yang tidak baik pada gurunya. Karena dengan menancapkan se butan atau label tersebut berulang-ulang dalam dirinya maka secara tidak langsung sudah menanam dan merawatnya dengan baik di alam bawah sadarnya dan akan menciptaklan sebuah jarak negative antar keduanya.

Penggunaan bahasa lisan, bahasa tulis dan bahasa tubuh tanpa disadari bisa menimbulkan, kekerasan psikologi banyak dilakukan oleh orang-orang dekat, seperti orang tua, anak, saudara maupun family. Kekerasan psikologis ini biasanya dilakukan melalui verbal atau bahasa tubuh yang dilakukan di depan orang banyak, misalnya dengan panggilan-panggilan yang kurang baik, dengan kebiasaan bicara keras. Dengan mengapresiai, menghargai dan menghormati guru, orang tua dan anak, baik ketika sedang berhadapan sendiri atau ketika sedang di depan orang lain, akan menciptakan suasana yang lebih nyaman untuk semua pihak. Apabila anak bersama dengan temannya diperlakukan kasar oleh orang-orang di dekatnya atau dipermalukan di depan orang lain. Peristiwa ini akan melekat dalam hati dan pikiran anak bahkan bisa 
menimbulkan stres. Bisa jadi mempengaruhi mental dan sikap anak pada orang lain. Hal ini juga bisa terjadi sebaliknya. Orang tua dan guru juga tidak ingin direndahkan di depan orang lain oleh eorang anak atau siswa. Orang tua lebih mudah menerapi dirinya sendiri dari pada seorang anak. Memang tidak ada seorang pun yang bisa terbebas dari stres, yang dapat dilakukan adalah menerima situasi stres tersebut sebagi sebuah kenyataan, atau berupaya mengurangi dampak stres tersebut seminimal mungkin. Namun, hal ini sulit dilakukan oleh anak untuk memhami dan menerapi diri sendiri.

\section{Hormon-hormon}

katekolamin seperti adrenalin, noradrenalin, dopamin memfasilitasi reaksi fisis langsung untuk mempersiapkan kerja otot yang kuat (memukul, menerjang atau lari). Respon stres dalam keadaan darurat bersifat vital untuk mempertahankan hidup. Namun, bila seorang tidak berhasil mengatasi stres, respon tersebut dapat mengganggu atau bahkan merusak sistem organ. Stres yang berkelanjutan akan merusak sistem kardiovaskular dan sistem imun yang akhirnya mengganggu kekebalan tubuh sehingga cepat sakit.

\section{SIMPULAN}

\section{Beberapa Solusi}

a. Adanya kesepakatan

Kesepakatan bisa dituangkan dalam bentuk aturan tulis maupun lisan.

Kesepakatan tulis bisa dituangkan dalam bentuk aturan sekolah, sedangkan kesepakatan lisan bisa disampaikan pada saat awal guru mengajar atau pada saat ada pertemuan formal guru siswa dan tenaga kependidikan (misalnya pada saat upacara sekolah)

b. Melalui Ketaladanan Untuk mendukung terlaksananya pendidikan dalam membentuk karakter anak, satuan pendidikan formal dan nonformal harus dikondisikn sebagai pendukung utama kegiatan tersebut. Satuan pendidikan formal dan nonformal harus menunjukkan keteladanan yang mencerminkan nilainilai karakter yang ingin dikembangkan. Misalnya berbicara dengan bahasa Indonesia yang baik, nada dan tekanan yang tidak mencerminkan emosi yang tinggi dan dengan bahasa tubuh yang beretika. Berpakaian rapi, datang tepat pada waktunya, bekerja keras, bertutur kata sopan, kasih sayang, perhatian terhadap orang-orang di sekitarnya dan orang yang membutuhkan perhatian, menjaga kebersihan dan sebagainya.

Keteladanan juga dapat ditunjukkan dalam perilaku dan sikap pendidik 
dan tenaga kependidikan dalam memberikan contoh tindakan-tindakan yang baik sehingga diharapkan menjadi panutan bagi anak. Pendemonstrasian berbagai contoh teldan merupakan langkah awal pembiasaan. Jika pendidik dan tenaga kependidikan yang lain menghendaki agar anak berperilaku dan bersikap sesuai dengan nilai-nilai karakter maka guru, orang tua dan masyarakat adalah orang pertama dan utama memberikan contoh bagaimana berperilaku dan bersikap sesuai dengan nilainilai tersebut.

c. Memberikan pujian dan kritik pada Bahasa verbal dan Perilaku siswa/guru

Menetapkan

sasaran untuk tidak berbicara negatif kepada anak, ketika terpaksa harus melakukannya, dengan menghindari mengecam pribadi dan sepak terjangnya, misalnya

- Tulisan tanganmu itu bukankan bisa diperbaiki lagi (dari pada tulisan tanganmu jelek ...)

- Seandainya dengan cara demikian apa bisa bapak/Ibu terima?

- Kamu memang anak yang kreatif dan bisa menjadi inspirasi temantemanmu!

- Saya $\begin{array}{r}\text { sangat } \\ \text { dengan }\end{array}$
terkesan
penjelasan
terimakakasih $/$ Ibu,
lebih paha jadi

d. Menghargai penutur lain melalui bahasa lisan dan bahasa tubuh yang baik Guru bisa memberikan petunjukkan bahasa-bahasa tubuh yang tidak baik dan guru juga tidak menggunakan bahasa tubuh tersebut dalam, komunikasi dengan siswa. Dan beberapa bahasa lisan $n$ tulisan yang tidak layak dignakan dalam komunikasi dengan guru.

\section{DAFTAR PUSTAKA}

Abidin, Yunus. (2015). Pembelajaran Bahasa Indonesia Berbasis Pendidikan Karakter. Bandung: Refika Aditama Daryanto dan Darmiatun, Suryatri. (2013). Implementasi Pendidikan Karakter di Sekolah. Jakarta: Airlangga Jay, Roni. (2009). The 10 Most ImportanThing You Can Do For Your Children (diterjemahkan oleh Ronaldo Tampubolon). Jakarta: Airlangga.

Lickona, Thomas. (2004). Character Matters. New York: Touchstone

Nurdin, Adnil Edwin. (2009). Tumbuh Kembang Perilaku Manusia. Jakarta: Penerbit Buku Kedokteran EGC. 
Saleh, Akh. Muwafik. (2012). Membangun Karakter dengan

Hati Nurani. Jakarta:

Airlangga. 